\title{
MODERATING ROLE OF USER EXPERIENCE AND IT RELIABILITY IN CONTROLLING INFLUENCE ON JOB PERFORMANCE AND ORGANIZATIONAL PERFORMANCE
}

\author{
Agnieszka Bieńkowska', Katarzyna Tworek², \\ Anna Zabłocka-Kluczka ${ }^{3}$
}

1 Wrocław University of Science and Technology, Faculty of Computer Science and Management, Department of Management Systems and Organizational Development, Poland, ORCID: 0000-0002-7498-6322, agnieszka.bienkowska@pwr.edu.pl;

2 Wrocław University of Science and Technology, Faculty of Computer Science and Management, Department of Management Systems and Organizational Development, Poland, ORCID: 0000-0002-6276-2436, katarzyna.tworek@pwr.edu.pl;

3 Wrocław University of Science and Technology, Faculty of Computer Science and Management, Department of Management Systems and Organizational Development, Poland, ORCID: 0000-0002-4743-2375, anna.zablocka-kluczka@pwr.edu.pl.

\begin{abstract}
Controlling is a method, which is most often used in contemporary organizations. The expectation of improvement of the organization's results is the most important reason of controlling implementation. The relation between controlling use and organizational performance is often taken for granted, however there are no comprehensive research explaining in detail how it affects results of organization functioning. The article attempted to fill in the existing research gap and explain how controlling affects results of organization functioning. The analysis concerned the impact of controlling use on both job performance and organizational performance. Since the job performance in case of controlling is increasingly dependent on the IT solutions, the analysis concerned the impact of IT reliability and User Experience (UX) on the developed model of the controlling influence on organizational performance. In that context the aim of the article was to clarify the mechanism of controlling use influence on organizational performance - considering the mediating role of job performance of employees and moderating role of IT solutions (the impact of UX and IT reliability on the relations between controlling, job performance and organizational performance). Formulated hypotheses were verified empirically on the sample of 637 organizations (349 operating in Poland and 288 operating in Switzerland). The presented results of empirical research allowed for the construction of a mediating model demonstrating the impact of controlling use on both job performance and organizational performance and shown that UX and IT reliability are moderators of the relation between the controlling use and job performance, and the relation between job performance and organizational performance.
\end{abstract}

Keywords: Controlling, organizational performance, job performance, IT reliability, user experience.

JEL Classification: C30, M15, M40, 033.

APA Style Citation: Bieńkowska, A., Tworek, K., \& Zabłocka-Kluczka, A. (2020). Moderating Role of User Experience and IT Reliability in Controlling Influence on Job Performance and Organizational Performance. E\&M Economics and Management, 24(1), 66-83. https://doi. org/10.15240/tul/2021-1-005

\section{Introduction}

Controlling is a method, which is most often used in contemporary organizations (Bieńkowska
\& Zgrzywa-Ziemak, 2011; Tworek, 2019c). "Importance of controlling increased sharply" (Guenther, 2013, p. 272), which in practice is 
confirmed by the growing number of job offers for controllers, and in theory by the number of academic centers dealing with this subject (Schäffer \& Binder, 2008). However, it is still considered by many as "a concept that is still subject of many controversies" (Mocanu, 2014, p. 62), and the diversity in the perception of this method is confirmed, among others, by information in the job announcements appearing on the job market (Behringer, 2011). The multi-threaded history of controlling promotes differences in the perception of controlling in the world, as well as the relative diversity of controlling solutions in organizations (e.g. Horvath, 2002). Nowadays, in European countries that built controlling systems based on German solutions, controlling is understood as subsystem supporting organization's management (Horvath, 2006), a method of management support (Bieńkowska, 2015, p. 38), support for planning and coordinating subsystems (Reichmann, 2011), or coordination of the management system (Küpper, 2008). In this approach, controlling is presented de facto as a method next to management, although it has a significant impact on this management (see Horvath, 2002; Reichmann, 2012). However, in the USA, which are considered to be the cradle of modern controlling (where the first controller positions were created and controllership was defined as a set of duties performed by controllers (e.g. Horvath, 2002)), as well as in other English-speaking European countries, controlling is combined directly with management and is often called "managerial/management control" (e.g. Otley, 1994, 1999; Granlund \& Taipaleenmäki, 2005; Anthony \& Govindarajan, 2007; Malmi \& Brown, 2008) or "managerial/ management control and accounting" (e.g. Emmanuel et al., 2013), where "management control systems provide information that is intended to be useful to managers in performing their jobs and to assist organizations in developing and maintaining viable patterns of behavior" (Otley, 1999, p. 364). In this way it refers not only to the tasks of controllers in the understanding of the German school, but also - often combined with information from management accounting - managerial activities in the organization. In this study, the theoretical approach based on the German understanding of controlling will be adopted. It is consistent with the fact that empirical research was carried out in Poland and Switzerland, where solutions based on the German concept of controlling are implemented in enterprises.

However, regardless of the differences in the perception of controlling, the system of information supply to the management is the main element of it (Serfling, 1992). As noticed by Reichmann (2012, p. 4) "information technology plays an increasingly important role [for controlling]. Without its support the information recording and processing tasks of an information-related Controlling were not manageable". Because of the information gathered by controlling - through its measurable and economical overtone - it is possible to make rational (and apt) decisions, and thus aimed at achieving the goals of the organization as a whole (Bieńkowska, 2015).

There is a very wide enumeration of aims of controlling functioning for the organization as a whole. The literature emphasizes the ability of controlling to influence the continuity of the organization's functioning, stimulating its development and increasing operating results, reducing the risk of the organization functioning, obtaining a competitive advantage or improving the effectiveness of organizations functioning (see Bea et al., 2005; Dellman, 1996; Nowosielski, 2001; Marciniak, 2008; Hahn \& Hungenberg, 2001; Weber, 1995; Kral, 2018). Thus, controlling influences the synthetically understood organizational performance, which refers to the comprehensive results of the functioning of the entire organization. Focus on performance target is underlined, e.g., by Hahn and Hungenberg (2001). It should be emphasized that the influence of controlling on each of the described categories, including the organizational performance, has an indirect character (see Bieńkowska, 2015). The simple implementation and use of controlling do not guarantee achievement of broadly defined goals and obtainment of the indicated benefits.

Therefore, it is necessary to clarify the way in which controlling affects the results obtained by organizations. Such a need is noticed by e.g. Deneke (2018) and Hartmann and Maas (2011). So far, the factors mediating in the influence of the use of controlling on the organizational performance have not determined in a comprehensive way, neither in literature nor in practice. Hence, there is a research gap.

The analysis of the role of mediating factors directly related to the work performed by 
managers and/or employees in the organization also seems to be a valid direction of research, regardless of whether the manager or employee has direct contact with controlling, or just uses the controlling products, i.e. the budgeting system, the cost and performance account or the information and reporting system. The work of managers and employees - because of controlling use - should be more efficient. In turn, higher job performance should result in improvement of organizational performance (Forooqui \& Nagendra, 2014; Sonnetag \& Frese, 2002). Therefore, it seems that the indirect influence of controlling use through job performance on organizational performance may be significant. It is partially demonstrated by Bieńkowska's research (2015), which concern the moderating effect of controlling on organizational performance through management quality, directly related to the work of managers. Horvath (2011, p. 96) also notes that controlling is a "subsystem of management system with the function of managerial performance-oriented coordination". However, controlling influences the organizational performance more broadly, by affecting the work of all employees in the organization: both managers and non-managerial employees.

It is also known that IT solutions are crucial for the work of controllers, and thus for the effectiveness of controlling (cf. Bieńkowska etal., 2019a, b; Tworek, 2019a). Dechow and Mouritsen (2005) underline that the implementation of integrated information systems defines a lot of aspects of management accounting. But Dechow et al. (2006, p. 625) also comment that "management accounting/control can easily be seen to be dependent on IT, but as we demonstrate IT cannot present its own case". Deneke (2018) also states that advanced and sophisticated IT solutions impact management accounting, performance and the organization in general. Moreover, the implementation of a proper IT solution is a prerequisite for the introduction of controlling into the organization (Bieńkowska, 2015; Goliszewski, 2015).

In this context, it is important to explain the impact of controlling on organizational performance through job performance and also attempt to examine the impact of IT on the relation between the use of controlling, job performance and organizational performance. IT solutions help to perform work not only by controllers (cf. Bieńkowska, 2015; Weißenberger
\& Angelkort, 2011), but also allow direct use of controlling products by controlling clients: managers and employees of organization (Huber, 1990; Deneke, 2018; Rom \& Rohde, 2007). More extensive research in this area should fill in the research gap, which is present in the literature and described earlier. However, it should be underlined that when considering the impact of IT on employees and the organization, two factors should be considered. One of them is IT reliability, which according to Tworek (2019a) concerns the use of IT in all of its dimensions (reliability of system itself together with its use, of information included in that system and of support services for this system) and User Experience (UX), which furthermore concerns not only user acceptance (included in the IT reliability), but also the perception of employee concerning widely understood system usability, ease of use and friendliness. It seems to be especially important in case of IT solutions supporting controlling, since the efficient and proper use of those solutions by employees is needed to ensure that support (Bieńkowska et al., 2019a; Tworek, 2019a).

In this context, the aim of the article is to clarify the mechanism of controlling use influence on organizational performance - considering the mediating role of job performance of employees and moderating role of IT solutions (the impact of UX and IT reliability on the relations between controlling, job performance and organizational performance).

\section{Theoretical Background}

\subsection{Controlling Influence on Job Performance and Organizational Performance}

Organizational performance is a synthetic, multidimensional and perhaps one of the most important constructs in modern management research (Richard et al., 2009), related to the results of organization's functioning as a whole. However, there is no universal measure of organizational performance that would suit any organization in all circumstances (Bieńkowska et al., 2018), as well as a way of defining it. According to Richard et al. (2009), this construct can be defined broadly or very narrow, as a part of wider and more general one: organizational effectiveness, and understood as a construct which "encompasses three specific areas of firm outcomes: (a) financial performance (...), 
(b) product market performance (...) and (c) shareholder return (...)" (Richard et al., 2009, p. 722). The contribution of balanced scorecard (BSC) to management theory (Kaplan \& Norton, 1996) has increased the attention given to wider aspects of organizational performance in management research, directing attentions of researchers to such issues as customer outcomes, innovation or internal processes. Together with changes in defining the organizational performance, the ways of measuring it has also changed. Historically, accounting and financial measures were most often used for this purpose, but in the context of dynamically changing business environment, it become obvious that explanatory power of financial measures is very limited and there is a need to look for other, more comprehensive solutions. So "the performance measurement has evolved from financial (...) to more complex structures, based on the balanced set of measures that seek to align these measures with the organization's strategy" (Beuren \& Teixeira, 2014, p. 169). They allow to achieve the balance between short and long-term goals and effects, explain the factors of future performance, are more understandable by the users of the information, and directly connect the management attention to the roots of the problems and not merely their consequences (Langfield-Smith et al., 2006).

Organizational performance is essential to the survival and achievement of success in the modern business. Hence, practitioners and management theorists do not cease in search of factors that shape it. There is a lot of factors that are judged by their contribution to organizational performance and controlling, as a management supporting method, is among them. Controlling is a method, which impact on the organizational performance is already proven. Generally, in the literature, it is assumed that controlling allows to ensure the continuity of the organization and stimulates its development (Bea et al., 2005), ensures the development and growth of the organization's position in a competitive fight (Dellman, 1988), improves the effectiveness and competitiveness of organizations functioning (Nowosielski, 2001; Marciniak, 2008), allows the organization to achieve economic efficiency (profitability) and financial liquidity (Hahn \& Hungenberg, 2001, as cited in Chachuła, 2009). Moreover, it affects the reduction of economic risk (Płóciennik-
Napierałowa, 2001), increase in the operating result of the entity (Kral, 2018), improves the processes efficiency (Deneke, 2018) and allows the achievement of management effectiveness and efficiency as well (Weber, 1995, as cited in Sierpińska \& Niedbała, 2003). Therefore, it impacts organizational performance, as a synthetic construct concerning the organization as a whole (see Benčová \& Kal'avská, 2009). This is partially confirmed by the results of some studies (Bieńkowska et al., 2019a, b, 2020). Moreover, "a controlling system acts as a subsystem of the management system, consequently being responsible for reaching the performance targets of the firm and systematically aligning the organization with the targets set previously" (Hahn \& Hungenberg, 2001, p. 265). Therefore, the following hypothesis can be formulated:

H1a: There is a relation between controlling use and organizational performance.

Job performance as a construct can be defined in different ways (June \& Mahmood, 2011). In general job performance refers to property of the behavior of employees (Motowidlo \& Kell, 2012; Sonnentag \& Frese, 2002). It concerns both behavioral and outcome aspects (Sonnentag \& Frese, 2002). In this paper, job performance will be understood as the effectiveness of employees' activities, which contribute to the realization of organizational goals (Forooqui \& Negendra, 2014, p. 95). Hence, job performance is "associated with the ability of the individual employees realizing their respective work goals, fulfilling expectations as well as attaining job targets and/or accomplishing a standard that are set by their organizations (Eysenck, 1998; Maathis \& Jackson, 2000; Bohlander et al., 2001)" (June \& Mahmood, 2011, p. 96).

The analysis of the controlling impact on the employees' job performance should include two groups of employees, regardless of whether they have direct or indirect contact with controlling. The first one consists of managers and the second one, of employees who do not occupy managerial positions. The managerial staff of the organization is a direct recipient of products offered by controlling. Based on the information provided by controlling, managers make decisions, both at the strategic and operational level of management. Marciniak (2008), underlines that the main aim of controlling is to enable 
managers to make more accurate (credible) decisions in the organization and translates into an increase in management's involvement in direct participation in the decision-making process (Nowosielski, 2001). Weber and Schäffer (2008) see controlling as rationality assurance for management decisions. In fact, it also translates directly into increasing job performance of managers, who can be seen as direct beneficiaries of controlling in the organization.

In turn, the implementation of controlling solutions in an organization increases the efficiency of management and productivity of all employees in the organization. The implementation of responsibility centers (signifying delegation of powers, setting partial objectives, as well as evaluating partial effectiveness and efficiency instead of global values), budgeting and analysis of results in a controlling approach, reporting or influencing the remuneration system, are ensuring budgetary discipline, access to current information and targeting the activity of cells on the result (e.g. Bieńkowska, 2015; Merchant, 1981). Moreover, Küpper (2008, as cited in Guenther, 2013) mentions coordination tools used in controlling within HRM i.e. management principles, target setting, incentive values, shared expectations and positive emotional interactions. This also means that it is possible to assume the existence of a direct impact of controlling solutions on the work of all employees in the organization. Based on those considerations, the following hypothesis can be formulated:

$H 1 b$ : There is a relation between controlling implementation and job performance.

Moreover, the issue of job performance of employees is a crucial factor determining the performance of entire organization (Forooqui, 2014). Brewer and Selden (2000) showed that among others (e.g. the structure of task/work, task motivation) individual performance is one of the most important predictors of organizational performance. As stated by Sonnetag and Frese (2002, p. 4), "organizations need highly performing individuals in order to meet their goals (...), and finally to achieve competitive advantage". That is mainly because highly performing employees are able to prone the organization to achieve the strategic aims and because of that, sustaining the competitive advantage (Lado \& Wilson, 1994; Dessler, 2011; June \& Mahmood, 2011).

Regardless of the above, there are a number of research works which show the influence of such factors as job satisfaction, work motivation, or organizational commitment on organizational performance (Kim, 2004; Koys, 2001; Jaramillo et al., 2005). Since they also impact the job performance (e.g. Carless, 2005, as cited in Meglino et al., 2000; Iqubal et al., 2013; Ali et al., 2018), it can be assumed that they indirectly prove the existence of the impact of job performance on organizational performance. In this context, the following hypothesis can be formulated:

H1c: There is a relation between job performance and organizational performance.

In the context of the relations described above, it seems that there is a need to analyze the impact of controlling use on organizational performance, while analyzing the mediating role of job performance. It will allow to verify and more comprehensively explain the mechanism of controlling use influence on organizational performance. Therefore, a hypothetical model of controlling use impact on organizational performance will be assumed, considering the mediating role of job performance, which is clearly connected to both of them. Therefore, in the light of the above, the main hypothesis should be formulated:

H2: Controlling use influence on the organizational performance (indirect effect) through the job performance (intermediary variable).

The diagram illustrating the adopted research hypotheses is presented in Fig. 1.

\subsection{Role of IT Reliability and UX in Controlling Influence on Job Performance and Organizational Performance}

The crucial role of IT solutions support for modern controlling is undisputable (Goliszewski, 2015; Bogt et al., 2016; Tworek, 2019a; Weißenberger et al., 2012; Peleias et al., 2009; Lira et al., 2012; Bieńkowska et al., 2018a; Menezes \& Riccio, 2005). However, it seems that there are some aspects of this support, which might be more important than others in case of enabling organization to rise its performance due to controlling use and IT support for this 


\section{Fig. 1: Controlling use influence on organizational performance through job performance}

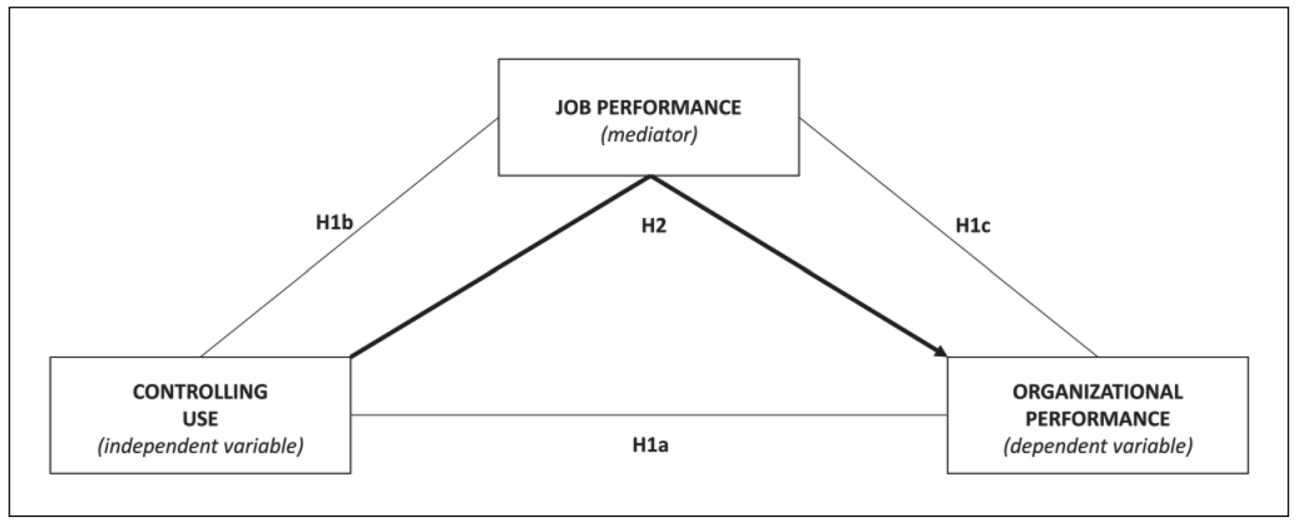

Source: own

management methods. In this paper, UX and IT reliability will be analyzed as such.

User Experience (in general) is defined as "all aspects of the user's experience when interacting with the product, service, environment or facility" (ISO 9241-11). However, the explanation of true meaning of UX in case of IT use by employees of organizations needs some more clarification. User Experience can be defined as a set of IT attributes (such as aesthetics, design, ease of use), which are created and developed to facilitate a good experience among employees (Tworek, 2019b; Law et al., 2014). Hence, the pragmatic and hedonic aims of individual employee, which show prioritization of importance of those attributes shape for the UX perceived by them (Tworek, 2019b). In this work, the model of Laugwitz et al. (2008) was adopted, in which UX consists of 6 factors gather those various attributes of IT: attractiveness (gathering general impression towards IT), efficiency (understood as the possibility of fast and efficient use of IT), perspicuity (understood as ease of use and learn how to interact with IT), dependability (understood as a sense of control over IT and its predictability), stimulation (gathering a set of consequences from using IT) and novelty (understood as innovation and creativity level of IT design) (Tworek, 2019b).

The reliability of IT in organization is defined as "a measurable property of IT, useful for its control and management, identifying its quality level and pointing out potential problems
(Zahedi, 1987) and it is directly linked to the efficiency of IT components, especially those critical to its proper operations" (Tworek, 2019a, p. 36). Therefore, it concerns the IT solutions ability to properly support all the tasks, which should be implemented be employees with the use of it. In this work, a shortened version of the IT reliability model developed by Tworek (2019a) was adopted, in which IT reliability consists of: reliability of information included in IT in organization (mostly its accuracy, relevance and accessibility), reliability of support services offered for IT in the organization (mostly their availability and responsiveness) and reliability of system itself (mostly availability, stability and security, but above all also including the usage reliability - its usability understood mostly as efficiency, acceptance and ease of use) (Tworek, 2019a).

The role of UX and IT reliability in strengthening the relation between controlling use and job performance is not properly analyzed yet. There are only some preliminary studies focused on this issue in the literature. Huber (1990) underlines that "information systems have a noticeable influence on decision-making within organizations" (as cited in Deneke, 2018, p. 129). Rom and Rohde (2007) are adding that enhanced integrated IT solutions can help management accountants to more efficiently perform their tasks. Deneke (2018) is also stating that implementation of more sophisticated IT solutions improves the relation between the managers and the 
management accountant. However, all of that is impossible without employees, who are willingly and efficiently using IT solutions aimed at supporting controlling use in the organization. The preliminary studies by Bieńkowska et al. (2019b) showed that IT reliability (including reliability of use) has the potential to influence the results obtained by the organization due to controlling implementation. The role of employees' perception of IT solutions should be furthermore analyzed. However, it can be already assumed that their positive UX and high reliability of IT solutions would greatly influence the benefits obtained from controlling use (Tworek, 2019a). In this context, the following hypotheses can be formulated:

H3a: The higher UX, the higher influence of controlling use on job performance.

H4a: The higher IT reliability, the higher influence of controlling use on job performance.

Task-technology Fit emphasizes the role of individual impact in generating value for organization from using IT solutions (Goodhue \& Thompson, 1995; Lai, 2017). Such an individual impact is usually understood as improved efficiency, effectiveness, and/or higher quality (Lai, 2017). This theory may be used as a starting point for the explanation that nowadays IT role is crucial for enabling the rise of organizational performance caused by the rise of individual job performance of employees. The main reason for that comes from the fact that job performance influence on organizational performance can be suspended by improperly used IT (when technology, for various reasons, does not fit the task). That is mainly because when employees are not properly trained and able to use IT, they are using it less efficiently and effectively and because of that, their job performance is not influencing the performance of the entire organization as strongly as in case of efficient and effective use of IT (Bipat et al., 2018). Among various IT value models, the role of IT adoption among employees as a prerequisite for enabling organizational performance is highly underlined (e.g. de Mendonca et al., 2008; Neirotti et al., 2008; Rush \& Melville, 2012; Sabherwal \& Jejyaraj, 2015; Bipat et al., 2018). In all of them, the authors suggest that job performance (or task performance) of employees can influence organizational performance to much greater extent when IT solutions used by employees are properly adopted by them (among others, accepted). Therefore, it seems that IT reliability and User Experience may be moderating the relation between job performance and organizational performance due to enabling efficient use of IT solutions. First of all, employees are more prone to properly and willingly use more reliable IT solutions (Tworek, 2019a) and the more reliable is the solution, the less time and effort they are spending to properly use it. Second of all, according to e.g. Laugwitz et al. (2008) and Law et al. (2014), employees are also more prone to properly use IT solutions, which are perceived by them as attractive, efficient and dependable (their UX with them

\section{Fig. 2: Moderating role of UX and IT reliability in model of controlling influence on organizational performance through job performance}

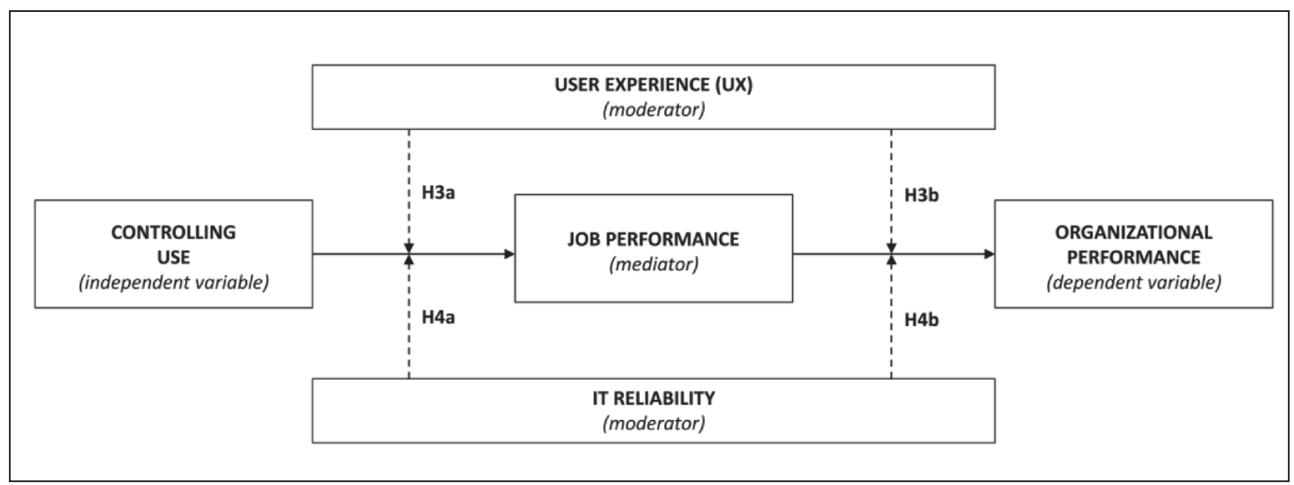


Tab. 1: Research sample characteristic

\begin{tabular}{l|c|c|c|c|c} 
& \multicolumn{4}{|c|}{ Time of operations } & \multirow{2}{*}{ Organization size } \\
\cline { 2 - 5 } & $\begin{array}{c}\text { Poland } \\
\text { (local org.) }\end{array}$ & $\begin{array}{c}\text { Poland } \\
\text { (branch } \\
\text { of a global } \\
\text { org.) }\end{array}$ & $\begin{array}{c}\text { Switzerland } \\
\text { (local org.) }\end{array}$ & $\begin{array}{c}\text { Switzerland } \\
\text { (branch } \\
\text { of a global } \\
\text { org.) }\end{array}$ & \multirow{2}{*}{ Total } \\
\hline Micro (below 10 people) & 24 & 58 & 40 & 3 & 125 \\
\hline Small (11-50 people) & 30 & 68 & 66 & 6 & 170 \\
\hline Medium (51-250 people) & 15 & 86 & 89 & 13 & 203 \\
\hline Large (above 250 people) & 12 & 56 & 63 & 8 & 139 \\
\hline Total & 81 & 268 & 258 & 30 & 637 \\
\hline
\end{tabular}

Source: own

is high). Hence, due enabling the proper use of IT solutions, both IT reliability and UX may strengthen the job performance influence on organizational performance. That is why the following hypotheses might be formulated:

$H 3 b$ : The higher UX, the higher influence of job performance on organizational performance.

H4b: The higher IT reliability, the higher influence of job performance on organizational performance.

The diagram illustrating the adopted research hypotheses is presented in Fig. 2 .

\section{Research Methodology}

The survey was conducted in order to verify the proposed mediation model and its moderators. The main survey was preceded by the pilot survey conducted among the group of 50 employees from various organizations (in late 2018) in order to explain the issues concerning ambiguity of several questions and respondent ability to understand what they are asked for. The main survey was conducted among employees from organizations located in Poland and Switzerland (in early 2019). It was the only condition limiting the sample obtained from a respondents' panel from SurveyMonkey.

The research sample contains the employees from organizations operating in Poland and Switzerland. 349 valid responses from Poland and 288 from Switzerland were collected. The sample is sufficiently diversified (considering diversity of organizations characteristics) to be a basis for overall conclusions concerning the given topic. Sample characteristics are presented in Tab. 1. They clearly show that the sample is covering diverse group of organizations.

\subsection{Variables Overview}

The hypotheses verification was based on five key variables: IT reliability, User experience, Controlling use, Job performance, Organizational performance.

IT reliability concerned all IT solutions used in the organization and was measured using a 5-points' Likert scale (the scale from very poor to very good with the middle point: fair). Based on that assessment one key variable was defined: IT reliability (constructed of 4 items: IT system reliability, IT information reliability, IT service reliability) (Tworek, 2019b).

User experience in organization was measured based on a 5-points' Likert scale, (the scale from very poor to very good with the middle point: fair) and the question concerning UX with used IT.

Controlling use was measured taking into consideration the respondent answer to the question: How long Controlling implemented in the organization? It was assessed on a 5-points' Likert scale (containing: not used, recently implemented, used more than a year, used more than 5 years, used more than 10 years).

Job performance was measured based on 4 items covering four areas: job quality, job efficiency, punctuality and effectiveness of achieving goals at the workplace, which are crucial for job performance of employees. The scale is based on a 5-point Likert scale (from: I strongly disagree, to: I strongly agree with 
a middle point: I have no opinion) (Ali-Hassan et al., 2015; Kwahk \& Park, 2018; Yuen et al., 2018).

Organizational performance was measured based on Balances Scorecard concept (Kaplan \& Norton, 1996), being the framework that allows to draw together multiple measures aimed at financial performance, internal business processes, customer perspectives, and innovation and learning. Within these 4 perspectives, 8 measures of the organizational performance were indicated. They were rated on the 5-points' Likert scale (from: well below expectations to: well above expectations with the middle point: as expected).

\subsection{Descriptive Statistics and Reliability Analysis of Scales}

The reliability of scales of each variable was verified for the obtained research sample and is presented in Tab. 3. The Cronbach's a was high for IT reliability, User experience, Job performance and Organizational performance, which indicates a high internal reliability of the scales and measurements. For Controlling use, it was not calculated, as it is a single-item variable.

\section{Research Results}

\subsection{Mediation Model}

According to Saks (2006), there are three conditions, which must be met to establish mediation model. First, the independent variables must be related to the mediator. Second, the dependent variables must be related to mediator. Third, a significant relations between the independent variables and dependent variables will be reduced (partial mediation) or no longer be significant (full mediation) when controlling for the mediator.

Therefore, first of all, the r-Pearson correlation analysis was performed in order to verify the first two conditions and verify hypotheses $H 1 a, H 1 b$ and $H 1 c$.

Obtained results, which are presented in Tab. 4, clearly show that there is a statistically significant and high correlation between all analyzed variables, however definitely the highest in case of the relation between job performance and organizational performance. It allows for the acceptance of hypotheses $\mathrm{H} 1 \mathrm{a}$, $\mathrm{H} 1 \mathrm{~b}$ and $\mathrm{H} 1 \mathrm{c}$.

Therefore, such a conclusion enables the next step and verify the mediating model of organizational performance. In order to do that, mediation model was built for Controlling use as independent variable, and Organizational performance as dependent variable. The Job performance will be tested as the mediator in the model. The obtained regression model should be statistically significant and the total effect should be higher than direct effect calculated for given variables. The results of the analysis are included in Tab. 5 .

The obtained regression model with mediator is statistically significant $(\mathrm{F} \quad(2.631)=797.561$ and corrected $\mathrm{R} 2=0.716)$. Moreover, job performance is a statistically significant mediator of the model $(p<0.001$, coeff. $=0.687$, se $=0.026)$. The mediating effect is also statistically significant, as can be observed in Tab. 5 , based on which it can be concluded that indirect effect is higher than the direct one, and also significant (BootLLCl $=0.305$ and BootULCI $=0.376$ and they are both above the value of 0 ). The obtained model shows that job performance is indeed a mediator of the relation between controlling

\section{Tab. 3: Defined variables along with the results of the reliability analysis of scales}

\begin{tabular}{c|l|c|c|c|c|c} 
No. & \multicolumn{1}{|c|}{ Variable } & $\begin{array}{c}\text { No. of } \\
\text { scales }\end{array}$ & Cronbach's a & Factor analysis & M & SD \\
\hline 1 & IT reliability & 4 & 0.912 & $80.21 \%$ & 3.51 & 1.13 \\
\hline 2 & User experience & 1 & - & - & 3.60 & 1.26 \\
\hline 3 & Controlling use & 1 & - & - & 2.86 & 1.50 \\
\hline 4 & Job performance & 4 & 0.923 & $81.30 \%$ & 3.68 & 1.12 \\
\hline 5 & Organizational performance & 8 & 0.946 & $72.44 \%$ & 3.55 & 1.04 \\
\hline
\end{tabular}


Tab. 4: Correlation analysis between analyzed variables

\begin{tabular}{l|l|c|c}
\multicolumn{2}{l}{} & Job performance & Organizational performance \\
\hline \multirow{4}{*}{ Controlling use } & r & 0.643 & 0.630 \\
\cline { 2 - 4 } & Sig. & $<0.001$ & $<0.001$ \\
\cline { 2 - 4 } & $\mathrm{N}$ & 638 & 638 \\
\hline \multirow{3}{*}{ Organizational performance } & $\mathrm{r}$ & 0.838 & 1 \\
\cline { 2 - 4 } & Sig. & $<0.001$ & - \\
\cline { 2 - 4 } & $\mathrm{N}$ & 638 & 638 \\
\hline
\end{tabular}

Source: own

Tab. 5: Job performance as the mediator of the relation between controlling use and organizational performance

\begin{tabular}{l|c|c|c|c|c}
\multicolumn{1}{c|}{ Mediator } & $\begin{array}{c}\text { Direct } \\
\text { effect value }\end{array}$ & $\begin{array}{c}\text { Indirect } \\
\text { effect value }\end{array}$ & Boot LLCI & Boot ULCI & R2 \\
\hline Job performance & 0.1117 & 0.3403 & 0.3050 & 0.3769 & 0.716 \\
\hline
\end{tabular}

Source: own

use and organizational performance. Therefore, it allows for accepting hypothesis $\mathrm{H} 2$.

\subsection{Moderators Analysis for the User Experience and IT Reliability - Research Results}

The obtained mediation model (hypothesis H2) was analyzed in the context of User experience and IT reliability to verify the statistical significance of them as moderators of the relations given in the model. The hypotheses were tested using regression analysis with moderator for two sets of relation:

- UX and IT reliability as the moderators of the relation between controlling use and job performance ( $\mathrm{H} 3 \mathrm{a}, \mathrm{H} 3 b)$;

- UX and IT reliability as the moderator of the relation between job and organizational performance (H4a, H4b).

The moderated regression analysis procedure was performed in both cases. In every case, a moderator was introduced as a new variable in the relation. It was built as a product of two independent variables, which have been standardized. Next, three regression models were built for every case using Process macro for IBM SPSS Statistics. The first one as a base one for comparison (and only independent variables were added as predictors). The second one using not only independent variables, but also the moderator as predictors. The aim was to verify the occurrence of the moderating influence in the entire sample. To confirm it, the third model was introduced using as predictors only moderator and one independent variable. The results of the analysis are presented in Tab. 6 .

The moderated regression analysis is a basis for two conclusions. First of all, the $\mathrm{R}^{2}$ obtained for all models allows for concluding that there is indeed a cause-effect relation between Controlling use, Job performance and Organizational performance, which is another way to verify the proposed model. Second of all, the obtained results clearly show that User experience is a statistically significant moderator in case of both relations: the relation between Controlling use and Job performance $(F(1.632)=461.214, p<0.001)$ and the relation between job performance and organizational performance $(\mathrm{F}(3.630)=330.219, \mathrm{p}<0.001)$. IT reliability is a statistically significant moderator also in case of both relations: the relation between Controlling use and Job performance $(\mathrm{F}(3.630)=428.917, \mathrm{p}<0.001)$ and the relation between Job performance and Organizational performance $(F(4.629)=639.990, p<0.001)$. Therefore, as shown in Tab. 6, obtained results are the basis for the acceptance of hypotheses $H 3 a, H 3 b, H 4 a$ and $H 4 b$. The hypotheses can 


\section{Tab. 6: Regression models' statistics}

\begin{tabular}{l|c|c|c|c|c|c}
\multicolumn{1}{c|}{ Model description } & $\mathbf{R}^{2}$ & Delta $\mathbf{R}^{2}$ & $\begin{array}{c}\text { Moderator } \\
\text { coeff. }\end{array}$ & $\begin{array}{c}\text { Standard } \\
\text { error }\end{array}$ & T Stat & P-value \\
\hline $\begin{array}{l}\text { User experience, } \\
\text { Controlling use, } \\
\begin{array}{l}\text { Moderator } \\
\text { Dependent v.: Job performance }\end{array}\end{array}$ & 0.598 & 0.025 & 0.041 & 0.021 & 1.966 & $0.049^{* *}$ \\
\hline $\begin{array}{l}\text { IT reliability, } \\
\text { Controlling use, } \\
\begin{array}{l}\text { Moderator } \\
\text { Dependent v.: Job performance }\end{array}\end{array}$ & 0.671 & 0.005 & 0.073 & 0.022 & 3.199 & $0.0014^{*}$ \\
\hline $\begin{array}{l}\text { User experience, } \\
\text { Job performance, }\end{array}$ & 0.766 & 0.010 & 0.030 & 0.018 & 1.657 & $0.0097^{*}$ \\
$\begin{array}{l}\text { Moderator } \\
\text { Dependent v.: Organ. performance }\end{array}$ & 0.802 & 0.003 & 0.061 & 0.020 & 3.035 & $0.0025^{* *}$ \\
\hline $\begin{array}{l}\text { IT reliability, } \\
\text { Job performance, } \\
\begin{array}{l}\text { Moderator } \\
\text { Dependent v.: Organ. performance }\end{array}\end{array}$ & & & & & \\
\hline
\end{tabular}

Source: own

Note: *accepted level of significance 0.001; **accepted level of significance 0.05 .

be accepted stating that both User experience and $I T$ reliability are moderators in a given mediation model.

In order to verify the results obtained from the step-by-step analysis made using SPSS Statistics, SPSS AMOS was used to perform the path-analysis. The path-model was verified in SPSS AMOS, it was well-fitted and statistically significant (Chi2 (3) = 7.317, $\mathrm{p}<0.005$; $\mathrm{TLI}=0.991 ; \mathrm{CFI}=0.906 ;$ RMSEA $=0.095$ ) Hence, it confirms the validity of obtained results, which were presented in detail in this chapter.

\subsection{Discussion}

The main focus of the study was to explain how controlling affects results of organization functioning. The obtained results are shown on Fig. 3.

The relation between controlling use and organizational performance is often taken for granted, because the expectation of

\section{Fig. 3: Results of moderating effects in a given mediation model}

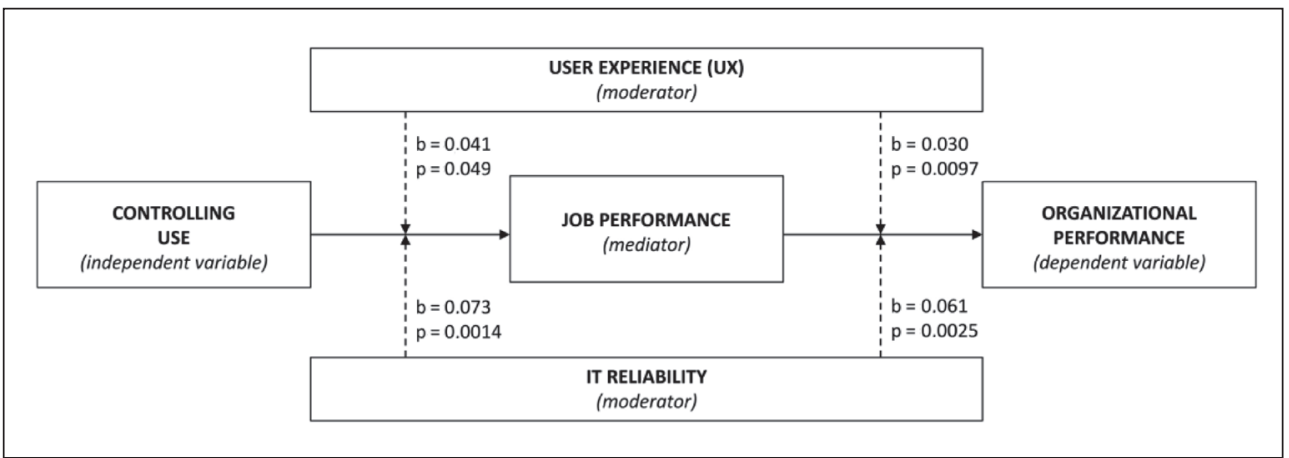


improvement of the organization's results is perhaps the most important reason of controlling implementation. It is often pointed that "its fundamental role is to provide professional support to increase business efficiency and profitability" (Lebar \& Kolar, 2015, p. 15) or to assure the rationality of management (Weber \& Schäffer, 2008). Apart from the situation when, for example, fashion or other non-substantive factors decide about its implementation, two the most important reasons are pointed: "striving to reduce operating costs ( $76.25 \%$ of responses) and striving to improve financial results (63.75\%)" (Bieńkowska \& Zgrzywa-Ziemak, 2011), both connected with the economic aspect of the organizations operations. The obtained research results confirmed that these expectations are not only wishful thinking, but a reality. Moreover, they allow to explain what is a mechanism of this influence. As it was previously pointed, the way in which controlling affects the results obtained by organizations is indirect. The verified mediation model shows that job performance mediates the relation between controlling use and organization performance, which partly explains the indirect effect of the controlling use on organizational performance. It turns out that controlling influences the results obtained by the organization, influencing the results obtained by employees (managers, controllers and non-executives), regardless of whether they have direct or indirect contact with controlling. When controlling is implemented, the work of managers (direct beneficiaries of the controlling) and employees (indirect beneficiaries of controlling) is characterized by greater efficiency and moreover, it affects the organization as a whole. In the case of direct beneficiaries of controlling, this is not a surprise. The range of instruments supporting the management offered by controlling and the partial efficiency measurement proposed by it becomes the basis for better managerial decisions and thus better management quality, which is a direct determinant of manager's job performance. This confirms in some way the results of the research of Bieńkowska (2015) and Küpper (2008). Moreover, controlling allows for the calculation, processing and transfer of information (financial and non-financial) referring not only to individual responsibility centers, but also more precisely distinguished cost centers or directly work places, that allows precise measurement of individual job performance, in many dimensions, not only from the point of view of work efficiency. Indirect beneficiaries of the controlling (those who do not use their services directly in their work but use the products of controlling) can better understand the financial and organizational framework of requirements and limitations of their work and also receive information about the assessment of their work. This, combined with knowledge of how to shape the remuneration system, may be the cause of greater self-control in work processes, reflected in job performance. For direct beneficiaries of the controlling system, this knowledge becomes the basis for managerial decisions (i.e. rewarding, the division of work and division of tasks), which also have an impact on the job performance of organization's employees, and further the organization's performance as a whole. The obtained results clearly confirmed that job performance is a mediator of the relation between controlling use and organizational performance, confirming the above theoretical assumptions.

Nowadays, information technology plays a central role in controlling. According to Schäffer and Weber (2016) and Weber et al. (2012) digitalization and IT development have radically changed the face of modern controlling. "The majority of its functions and tasks have become automatized, leaving room to integrate its working field with business analytics, strategic planning and internal consultancy" (Lebar \& Kolar, 2015, p. 14). Hence, the basic tool of controllers' work are now IT solutions. Being crucial for the work of controllers, they are also crucial for the effectiveness of the controlling itself. IT solutions created for the use of controlling can have various levels of advancement from simple spreadsheets and non-integrated management support systems, often created in specific organizations to off-the shelf, modular, integrated management support systems, which are universal, though personalized in terms of the needs of specific organizations (Bieńkowska et al., 2017, 2019b). They offer various functionalities and differ in case of difficulty, intuitive operation, or adaptation to the needs of users. They can stimulate the creation of increasingly sophisticated controlling products (i.e. multidimensional analyzes), or discourage employees from using them, which has a direct impact on the results of 
work, and indirectly - on the results of the entire organization. However, regardless of the level of advancement and the scope of adjustments to the needs of the specific organization, IT tools will perform their functions well only in case they will be reliable, since unreliable IT often hinders, and sometimes directly prevents the correct implementation of tasks at the workplace, which obviously translates into lower job performance and thus worse results of the organization as a whole. Thus, it was assumed that IT reliability can be important moderator of relation of controlling use influence on job performance. The obtained research results clearly confirmed this thesis and showed that the higher the IT reliability, the stronger the influence of controlling use on job performance. Moreover, it was also assumed that UX is the factor that can influence the level of job performance achieved thanks to controlling use. According to universally accepted opinion, IT has an impact on the object (in this case organization) not directly - but only through the people (users - system operators), whose willingness, skills and attitudes determine organization's efficiency (Rogalski \& Niedźwiedziński, 2010). Experiences of users, based on their feelings and opinions determine the level of subjective attractiveness of IT solutions and their usefulness as well as the effectiveness of their use in the organization. Also, in that case, the obtained research results clearly confirmed that the higher the UX, the stronger the influence of controlling use on job performance. Both, IT reliability and UX are hence a statistically significant moderator of the relation between controlling use and job performance.

Moreover, IT is nowadays used by all users (managers and other groups of employees) at all organization levels. There is not only a specific technology that helps solving particular work tasks (such as, e.g., ERP, CRM or SCM systems), but also very simple devices like e.g. computer/laptop, mobile phone, SMS, smart phone, GPS or internet used just to communicate or co-ordinate task realization. It is undisputable that IT usage affects organizational performance (Tworek, 2019a). However, it is then important how the IT solutions influence organizational performance or which characteristics of IT solutions cause that organizational effects of their usage to be stronger. In the paper it was assumed that reliability of available IT and UX can also affect the influence of job performance on organizational performance. The obtained results confirmed those suppositions and clearly showed that higher IT reliability and UX (resulting in more efficient use of IT) causes that the job performance of employees is influencing the performance of the entire organization much stronger than in case of of inefficient and ineffective use of IT. Hence, providing appropriate, reliable IT solutions, which fit tasks and are accepted by direct users, seems to be important for enhancing organizational performance. It leads also to conclusion that even a small change in the level of job performance of employees who are more prone to properly use IT solutions, perceived by them as attractive, efficient and dependable, will lead to the disproportionally larger change in organizational performance.

The obtained results lead to interesting conclusions. First of all, the fact that both IT reliability and UX are a statistically significant moderator of the both relation in the given mediation model is a source of important premises for management, and in particular for the implementation of IT solutions supporting controlling. There is a lot of factors determining the selection of an IT solution for controlling, starting from political arguments (warrant from headquarters), through substantive arguments (possibility of achieving organization's goals, results presentation transparency, relation of outcomes to effects, IT solution flexibility, data processing time, access to information, etc) and ending on cost arguments. Above research confirmed that specification of information expectations of future IT solution users is one the most important. Thus, when choosing an IT solution for controlling, great emphasis should be placed on: firstly, its reliability, and secondly its attractiveness for direct users, because they will decide about its future effectiveness. Moreover, the question arises: how to build the positive UX in situation, when it is not always possible to consider user requirements at the stage of selection and implementation of IT solution for controlling. It seems that the answer lies in the management area: in the training system, or giving the controlling solutions' users the opportunity to independently develop existing solutions and tailor them to their needs, while providing adequate substantive support in this regard. 


\section{Conclusions}

Although the fundamental role of controlling is to provide professional support to increase business efficiency and profitability, till now the factors that mediate the influence of the use of controlling on organizational performance were not specified. Such a research gap was fulfilled by the performed literature analysis complemented with empirical research. First of all, the hypothetical model of relations between controlling use and organizational performance mediated by job performance was introduced. The model was empirically verified, which confirmed the role of job performance as a mediator of this relation. Therefore, the first aim of the article (to examine the impact of controlling use on organizational performance) was successfully fulfilled.

At the same time, the aim of the article was to examine the impact of IT on the relations between the use of controlling, job performance further organizational performance, for a more detailed explanation of the impact of controlling use on the organizational performance through job performance. For this purpose, UX and IT reliability role in moderating the relations between controlling use, job performance and organizational performance was empirically verified. The obtained results confirmed that both UX and IT reliability are moderators in a given mediation model. However, they are moderating two different relations within the model. This allowed to successfully fulfill the second aim of the article.

However, the presented empirical study has some limitations. Unfortunately, the survey did not include question asking whether employee directly uses the services and/or products of controlling. Such a question would allow a more in-depth analysis of the impact of controlling use on the job performance of employees in the organization. Therefore, the performed analysis points to the future direction of research, aiming at further development of the model and inclusion of other notions, which are arising as important for modern employees but are not yet tackled in the literature. At the same time, the unequal distribution of the research sample, in which there is a domination of employees from very large and micro-sized organizations, is a certain limitation for the interpretation of results.

The results of research have important implications for the development of knowledge in the field of the organization and management science. First of all, built and empirically verified model confirming the mediation role of the job performance between controlling use and organizational performance fills in clearly existing gap. Observation that IT reliability and UX are the moderators in a given mediation model contribute new knowledge to the field of management and computer science. Moreover, conducted research in an indirect way proves the impact of controlling on every employee in the organization, regardless of whether one is its direct beneficiary or indirect beneficiary. And finally, high dependence of individual job performance on IT reliability and UX shows the need for a deeper analysis of factors affecting employees' perception of IT solutions and the need to extend the classic job characteristics to issues related to the use of IT tools.

\section{References}

Ali, M., Lodhi, S. A., Raza, B., \& Ali, W. (2018). Examining the impact of managerial coaching on employee job performance: Mediating role of work engagement, leadermember-exchange quality, job satisfaction and turnover intentions. Pakistan Journal of Commerce and Social Sciences, 12(1), 253-282.

Ali-Hassan, H., Nevo, D., \& Wade, M. (2015). Linking dimensions of social media use to job performance: The role of social capital. The Journal of Strategic Information Systems, 24(2), 65-89. https://doi.org/10.1016/j. jsis.2015.03.001

Anthony, R. N., \& Govindarajan, V. (2007). Management control systems (12th ed.). Boston, MA: McGraw-Hill/Irwin.

Bea, F., Friedl, B., \& Schweitzer, M. (2005). Allgemeine Betriebswirtschaftslehre, Bd. 2: Führung. Stuttgart: UTB.

Behringer, S. (2011). Konzerncontrolling. Berlin, Heidelberg: Springer-Verlag. https://doi. org/10.1007/978-3-642-13156-1

Benčová, M., \& Kal'avská, A. (2009). Importance of the Controllership for the Company Performance-Software Company Experience. E\&M Economics and Management, 12(2), 76-83.

Beuren, I. M., \& Teixeira, S. A. (2014). Evaluation of management control systems in a higher education institution with the performance management and control. Journal of Information Systems and Technology Management, 11(1), 169-192. https://doi. org/10.4301/s1807-17752014000100010 
Bieńkowska, A. (2015). Analiza rozwiązań $i$ wzorce controllingu $w$ organizacji. Wrocław: Oficyna Wydawnicza Politechniki Wrocławskiej.

Bieńkowska, A., Kral, Z., \& ZabłockaKluczka, A. (2017). IT tools used in the strategic controlling process: Polish national study results. In I. Šimberová, A. Kocmanová, \& F. Milichovský (Eds.), Perspectives of Business and Entrepreneurship Development in Digital Age: Economics, Management, Finance and System Engineering from the Academic and Practioners Views, proceeding of selected papers (pp. 75-84). Brno, Czech Republic.

Bieńkowska, A., Tworek, K., \& ZabłockaKluczka,A. (2019a). ITReliability and the Results of Controlling. In Z. Wilimowska, L. Borzemski, \& J. Świątek (Eds.), Information Systems Architecture and Technology: Proceedings of 39th International Conference on Information Systems Architecture and Technology - ISAT 2018. Advances in Intelligent Systems and Computing (Vol. 854, pp. 222-234). Cham: Springer. https://doi.org/10.1007/978-3-31999993-7_20

Bieńkowska, A., Tworek, K., \& ZabłockaKluczka, A. (2019b). Information technology reliability influence on controlling excellence. The International Journal of Digital Accounting Research, 19, 1-28. https://doi. org/10.4192/1577-8517-v19_1

Bieńkowska, A., Tworek, K., \& ZabłockaKluczka, A. (2020). IT Reliability and Its Influence on the Results of Controlling: Comparative Analysis of Organizations Functioning in Poland and Switzerland. Information Systems Management, 37(1), 33-51. https://doi.org/10.1 080/10580530.2020.1696545

Bieńkowska, A., \& Zgrzywa-Ziemak, A. (2011). Współczesne metody zarządzania w przedsiębiorstwach funkcjonujących w Polsce - identyfikacja stanu istniejącego. In M. Hopej \& Z. Kral (Eds.), Współczesne metody zarządzania w teorii i praktyce (pp. 211-252). Wrocław: Oficyna Wydawnicza Politechniki Wrocławskiej.

Bipat, S., Sneller, L., Visser, J., \& Rouwelaar, H. (2018). Understanding the Relation between Information Technology Capability and Organizational Performance. Research-inProgress Papers, 41. https://aisel.aisnet.org/ ecis2018_rip/41

Bogt, H. T., van Helden, J., \& van der Kolk, B. (2016). New development: Public sector controllership - reinventing the financial specialist as a countervailing power. Public Money \& Management, 36(5), 379-384. https:// doi.org/10.1080/09540962.2016.1194086

Bohlander, G., Snell, S., \& Sherman, A. (2001). Managing human resources. Cincinnati, $\mathrm{OH}$ : South-Western College Publishing.

Brewer, G. A., \& Selden, S. C. (2000). Why Elephants Gallop: Assessing and Predicting Organizational Performance in Federal Agencies. Journal of Public Administration Research and Theory, 10(4), 685-711. https://doi.org/10.1093/ oxfordjournals.jpart.a024287

Carless, S. A. (2005). Person-job fit versus person-organization fit as predictors of organizational attraction and job acceptance intentions: A longitudinal study. Journal of Occupational and Organizational Psychology, 78(3), 411-429. https://doi. org/10.1348/096317905×25995

Chachuła, D. (2009). Controlling. Koncepcje, narzędzia, modele. Warszawa: Difin.

de Mendonca, M. A. A., Freitas, F., \& de Souza, J. M. (2008). Information Technology and Productivity: Evidence for Brazilian Industry from Firm-Level Data. Information Technology for Development, 14(2), 136-153. https://doi. org/10.1002/itdj.20091

De Lira, A. M. D., Parisi, C., Peleias, I. R., \& Peters, M. R. S. (2012). Uses of ERP systems and their influence on controllership functions in Brazilian Companies. Journal of Information Systems and Technology Management, 9(2), 323-352. https://doi.org/10.4301/s180717752012000200007

Dechow, N., \& Mouritsen, J. (2005). Enterprise resource planning systems, management control and the quest for integration. Accounting, organizations and society, 30(7-8), 691-733. https://doi.org/10.1016/j.aos.2004.11.004

Dechow, N., Granlund, M., \& Mouritsen, J. (2006). Management control of the complex organization: Relationships between management accounting and information technology. Handbooks of Management Accounting Research, 2, 625-640. https://doi. org/10.1016/s1751-3243(06)02007-4

Dellmann, K. (1988). Eine Systematisierung der Grundlagen des Controlling. In K. Spremann \& E. Zur (Eds.), Controlling: Grundlagen - Informationssysteme - Anwendungen (pp.113-140). Wiesbaden: Gabler Verlag.

Deneke, A. (2018). Integrated information systems: The influence on process performance in management accounting. 
Junior Management Science, 3(1), 123-159. http://dx.doi.org/10.5282/jums/v3i1pp123-159

Dessler, G. (2011). Human Resource Management (12th ed.). Upper Saddle River, $\mathrm{NJ}$ : Prentice-Hall.

Emmanuel, C., Otley, D., \& Merchant, K. (2013). Readings in Accounting for Management Control. Cham: Springer.

Eysenck, M. (1998). Psychology: An Integrated Approach. New York, NY: AddisonWesley Longman Ltd.

Farooqui, M. S., \& Nagendra, A. (2014). The impact of person organization fit on job satisfaction and performance of the employees. Procedia Economics and Finance, 11, 122-129. https://doi.org/10.1016/s2212-5671(14)00182-8

Granlund, M., \& Taipaleenmäki, J. (2005). Management control and controllership in new economy firms - a life cycle perspective. Management Accounting Research, 16(1), 21-57. https://doi.org/10.1016/j.mar.2004.09.003

Goliszewski, J. (2015). Controlling. Koncepcja, zastosowania, wdrożenie. Warszawa: Oficyna a Wolters Kluwer business.

Goodhue, D. L., \& Thompson, R. L. (1995). Task technology fit and individual performance. MIS Quarterly, 19(2), 213-236. https://doi. org/10.2307/249689

Guenther, T. W. (2013). Conceptualisations of 'controlling' in German-speaking countries: analysis and comparison with Anglo-American management control frameworks. Journal of Management Control, 23(4), 269-290. https://doi.org/10.1007/s00187-012-0166-7

Hahn, D., \& Hungenberg, H. (2001). Planung und Kontrolle - Planungs- und KontrollsystemePlanungs- und Kontrollrechnung. Wertorientierte Controllingkonzepte (6th ed.). Wiesbaden: Springer Gabler.

Hartmann, F. G. H., \& Maas, V. S. (2011). The effects of uncertainty on the roles of controllers and budgets: An exploratory study. Accounting and Business Research, 41(5), 439-458. https://doi.org/10.1080/00014788.20 11.597656

Horvath, P. (2002, 2006). Controlling. München: Verlag Franz Vahlen.

Huber, G. P. (1990). A theory of the effects of advanced information technologies on organizational design, intelligence, and decision making. Academy of Management Review, 15(1), 47-71. https://doi.org/10.2307/258105

lqbal, N., Ahmad, N., Majid, M., Nadeem, M., Javed, K., Zahra, A., \& Aheeq, M. (2013).
Role of employee motivation on employee's commitment in the context of banking sector of DG KHAN, Pakistan. Journal of Human Resource Management, 1(1), 1-8. https://doi. org/10.11648/j.jhrm.20130101.11

ISO. (2008). ISO CD 9241-210 Ergonomics of human - system interaction - Part 210: Human-centered design process for interactive systems. ISO.

Jaramillo, F., Mulki, J. P., \& Marshall, G. W. (2005). A meta-analysis of the relationship between organizational commitment and salesperson job performance: 25 years of research. Journal of Business Research, 58(6), 705-714. https://doi.org/10.1016/j. jbusres.2003.10.004

June, S., \& Mahmood, R. (2011). The relationship between person-job fit and job performance: A study among the employees of the service sector SMEs in Malaysia. International Journal of Business, Humanities and Technology, 1(2), 95-105.

Kaplan, R. S., \& Norton, D. P. (1996). The balanced scorecard: translating strategy into action. Boston, MA: Harvard Business School Press.

Kim, S. (2004). Individual-level factors and organizational performance in government organizations. Journal of Public Administration Research and Theory, 15(2), 245-261. https://doi.org/10.1093/jopart/mui013

Koys, D. J. (2001). The effects of employee satisfaction, organizational citizenship behavior, and turnover on organizational effectiveness: A unit-level, longitudinal study. Personnel Psychology, 54(1), 101-114. https:// doi.org/10.1111/j.1744-6570.2001.tb00087.x

Kral, D. (2018). Analysis of the impact of the controlling operational system on the unit's operating result. Systemy Wspomagania w Inżynierii Produkcji, 7(3), 271-280.

Küpper, H.-U. (1987). Konzeption des Controlling aus betriebswirtschaftlicher Sicht. In W.-A. Scheer (Ed.), Rechnungswesen und EDV. Saarbrücker Arbeitstagung 1987 (Vol. 8, pp. 82-116). Heidelberg: Physica-Verlag HD. https://doi.org/10.1007/978-3-642-48031-7_4

Küpper, H.-U. (2008). Controlling Konzeption, Aufgaben, Instrumente. Stuttgart: SchäfferPoeschel.

Kwahk, K.-Y., \& Park, D.-H. (2018). Leveraging your knowledge to my performance: The impact of transactive memory capability on job performance in a social media environment. 
Computers in Human Behavior, 80, 314-330. https://doi.org/10.1016/j.chb.2017.10.047

Lado, A. A., \& Wilson, C. M. (1994). Human resource systems and sustained competitive advantage: A competency-based perspective. Academy of Management Review, 19(4), 699-727. https://doi.org/10.5465/ amr.1994.9412190216

Lai, P. C. (2017). The literature review of technology adoption models and theories for the novelty technology. JISTEM-Journal of Information Systems and Technology Management, 14(1), 21-38. https://doi.org/10.4301/s180717752017000100002

Langfield-Smith, K., Thorne, H. T., \& Hilton, R. W. (2006). Management Accounting: information for managing and creating value (4th ed.). North Ryde: McGrawHill.

Laugwitz, B., Schrepp, M., \& Held, T. (2008). Construction and evaluation of a User Experience questionnaire. In A. Holzinger (Ed.), $\mathrm{HCl}$ and Usability for Education and Work. USAB 2008. Lecture Notes in Computer Science (Vol. 5298, pp. 63-76). https://doi. org/10.1007/978-3-540-89350-9_6

Law, E. L.-C., van Schaik, P., \& Roto, V. (2014). Attitudes towards User Experience (UX) Measurement. International Journal of HumanComputer Studies, 72(6), 526-541. https://doi. org/10.1016/j.ijhcs.2013.09.006

Lebar, D., \& Kolar, I. (2015). Controllership Influences on the Restructuring of Slovenian Companies. Our Economy, 61(4), 14-22. https://doi.org/10.1515/ngoe-2015-0014

Maathis, R. L., \& Jackson, J. H. (2000). Human resource management. Cincinnati, $\mathrm{OH}$ : South-Western College Publishing.

Malmi, T., \& Brown, D. A. (2008). Management control systems as a package - Opportunities, challenges and research directions. Management Accounting Research, 19(4), 287-300. https://doi.org/10.1016/j. mar.2008.09.003

Marciniak, S. (2008). Controlling. Teoria, zastosowania. Warszawa: Difin.

Meglino, B. M., Ravlin, E. C., \& DeNisi, A. S. (2000). A meta-analytic examination of realistic job preview effectiveness: A test of three counterintuitive propositions. Human Resource Management Review, 10(4), 407-434. https://doi.org/10.1016/s1053-4822(00)00034-6

Menezes, L. L., \& Riccio, E. L. (2005). Relacionamento entre a controladoria e a gestão da informação econômico-financeira na nova economia. Revista Brasileira de Gestão de Negócios, 7(18), 34-50.

Merchant, K. A. (1981). The design of the corporate budgeting system: influences on managerial behavior and performance. Accounting Review, 56(4), 813-829.

Mocanu, M. (2014). Towards a definition of controlling. Studies and Scientific Researches. Economics Edition, 20. https://doi.org/10.29358/ sceco.v0i20.295

Motowidlo, S. J., \& Kell, H. J. (2012). Job performance. Handbook of Psychology (2nd ed., Vol. 12). Hoboken, NJ: John Wiley \& Sons. https://doi.org/10.1002/9781118133880.hop212005

Neirotti, P., Cantamessa, M., \& Paolucci, E. (2008). Do Companies with a Competitive Advantage make Better Use of IT? Evidence from Italian Enterprises. International Journal of Technology Management, 42(1/2), 158-184. https://doi.org/10.1504/ijtm.2008.018066

Nowosielski, S. (2001). Centra kosztów i centra zysku w przedsiębiorstwie. Wrocław: Wydawnictwo Akademii Ekonomicznej im. Oskara Langego we Wrocławiu.

Otley, D. (1994). Management control in contemporary organizations: towards a wider framework. Management Accounting Research, 5(3-4), 289-299. https://doi.org/10.1006/ mare.1994.1018

Otley, D. (1999). Performance management: a framework for management control systems research. Management Accounting Research, 10(4), 363-382. https://doi.org/10.1006/ mare.1999.0115

Peleias, I. R., Trevizoli, J. C., Côrtes, P. L., \& Galegale, N. V. (2009). Pesquisa sobre a percepção dos usuários dos módulos contábil e fiscal de um sistema erp para o setor de transporte rodoviário de cargas e passageiros. Revista de Gestão da Tecnologia e Sistemas de Informação, 6(2), 247-270. https://doi. org/10.4301/S1807-17752009000200006

Płóciennik-Napierałowa, J. (2001). Controlling - nowoczesne narzędzie zarządzania. Rachunkowość, 6, 361-368.

Reichmann, T. (2011). Controlling mit Kennzahlen und Management-Tools. Die systemgestützte Controlling-Konzeption (8th ed.). München: Vahlen.

Reichmann, T. (2012). Controlling: concepts of management control, controllership, and ratios. Berlin/Heidelberg: Springer Science \& Business Media.

Richard, P. J., Devinney, T. M., Yip, G. S., \& 
Johnson, G. (2009). Measuring organizational performance: Towards methodological best practice. Journal of Management, 35(3), 718804. https://doi.org/10.1177/0149206308330560

Rogalski, M., \& Niedźwiedziński, M. (2010). Subiektywna a obiektywna ocena systemu informatycznego na przykładzie firmy sprzedaży wysyłkowej. Polskie Stowarzyszenie Zarządzania Wiedzą, Seria: Studia i Materiały, 29, 125-137.

Rom, A., \& Rohde, C. (2007). Management accounting and integrated information systems: A literature review. International Journal of Accounting Information Systems, 8(1), 40-68. https://doi.org/10.1016/j.accinf.2006.12.003

Rush, D. E., \& Melville, N. P. (2012). Do Carbon Management System Adoption Announcements Affect Market Value? In Proceedings of the 33rd International Conference on Information Systems, Orlando, FL.

Sabherwal, R., \& Jeyaraj, A. (2015). Information Technology Impacts on Firm Performance: An Extension of Kohli and Devaraj (2003). MIS Quarterly, 39(4), 809-836.

Saks, A. M. (2006). Antecedents and consequencesofemployeeengagement. Journal of Managerial Psychology, 21(7), 600-619. https://doi.org/10.1108/02683940610690169

Schäffer, U., \& Binder, C. (2008). Controlling' as an academic discipline: The development of management accounting and management control research in Germanspeaking countries between 1970 and 2003. Accounting History, 13(1), 33-74. https://doi. org/10.1177/1032373207083926

Schäffer, U., \& Weber, J. (2016). Die Digitalisierung wird das Controlling radikal verändern. Controlling \& Management Review, 60(6), 6-17. https://doi.org/10.1007/s12176016-0093-9

Serfling, K. (1992). Controlling (2nd ed.). Stuttgart: Kohlhammer.

Sierpińska, M., \& Niedbała, B. (2003). Controlling operacyjny $w$ przedsiębiorstwie. Warszawa: Wydawnictwo Naukowe PWN.
Sonnentag, S., \& Frese, M. (2002). Performance concepts and performance theory. Psychological Management of Individual Performance, 23(1), 3-25. https:// doi.org/10.1002/0470013419.ch1

Tworek, K. (2019a). User Experience influence on reliability of IT in organization in the context of job characteristics. Central European Business Review, 8(1), 33-49. https://doi. org/10.18267/j.cebr.210

Tworek, K. (2019b). Aligning IT with business. Cham: Springer. https://doi. org/10.1007/978-3-030-11563-0

Tworek, K. (2019c). IT reliability as a manifestation of the alignment between information systems in organization and the needs of chosen management techniques. International Journal of Business and Management Invention, 8(1), 23-31. https://doi. org/10.1080/23311975.2018.1522752

Weber, J. (1995). Einführung in das Controlling (6th ed.). Stuttgart: Schäffer-Poeschel Verlag.

Weber, J., \& Schäffer, U. (2008). Introduction to Controlling. Stuttgart: SchäfferPoeschel Verlag.

Weber, J., Strauß, E., \& Spittler, S. (2012). Controlling \& IT: Wie Trends und Herausforderungen der IT die Controllingfunktion verändern. Controlling \& Management Review, 56(2), 105-109. https://doi.org/10.1365/s12176012-0127-x

Weißenberger, B. E., Angelkort, H., \& Holthoff, G. (2012). MAS integration and controllership effectiveness: Evidence of a preparer-user perception gap. Business Research, 5(2), 134-153. https://doi.org/10.1007/bf03342735

Yuen, K. F., Loh, H. S., Zhou, Q., \& Wong, Y. D. (2018). Determinants of job satisfaction and performance of seafarers. Transportation Research Part A: Policy and Practice, 110, 1-12. https://doi.org/10.1016/j.tra.2018.02.006

Zahedi, F. (1987). Reliability of information systems based on the critical success factorsformulation. MIS Quarterly, 11(2), 187-203. https://doi.org/10.2307/249362 